\title{
Resenären, samlaren, berättaren
}

\section{Bruce Chatwin i Patagonien}

Bruce Chatwins litterära karriär blev exceptionellt kort. Han debuterade som författare 1977, i den relativt höga åldern av 37 år, och utgav sin sista skönlitterära bok bara elva år senare, då han tynade bort i en mystisk benmärgssjukdom orsakad av aids. I hans totala œuvre är det också bara ett par verk - romanerna On the Black Hill (1982) och Utz (1988) - som kan sägas utgöra fiktion i ordets konventionella bemärkelse. Resten består av reseskildringar, essäer, artiklar, anteckningar och fotografier, varav åtskilligt har publicerats posthumt. ${ }^{1}$ Inte desto mindre uppnådde Chatwin en så stor berömmelse att han efter sin död närmast har förvandlats till en legend. Hans böcker har översatts till 27 språk, tre av dem har filmatiserats i stor stil, ${ }^{2}$ och hans liv har redan gjorts till föremål för ett par omfattande biografier. ${ }^{3}$ Som om detta inte vore nog finns det numera boklådor, konstgallerier och förlag som har uppkallat sig efter honom eller hämtat sina namn från hans verk. Popgrupper i England citerar honom i sina sånger, och så vidare.

Hur skall man egentligen förklara denna succé? En av orsakerna är utan tvivel att Chatwin, i likhet med sådana litterära kultfigurer som Oscar Wilde och T.E. Lawrence, mer eller mindre avsiktligt mytologiserade sin egen person. En annan och därmed besläktad förklaring är givetvis att han var en gudabenådad berättare. Men hemligheten bakom hans berättarkonst är förmodligen att han återupptäckte och förnyade en litterär genre som nästintill hade fallit i glömska när han 1977 slog igenom med sin reseskildring In Patagonia.

1. Chatwins samlade journalistik trycktes under titeln What Am I Doing Here? kort efter hans död 1989. Därefter har ytterligare tre böcker av honom getts ut: Photographs and Notebooks, London1993, Anatomy of Restlessness, London 1996, och Winding Paths: Photographs by Bruce Chatwin, London 1999.

2. On the Black Hill av Andrew Grieve (1987), The Viceroy of Ouidah (omdöpt till Cobra Verde) av Werner Herzog (1990) och Utz av George Sluizer (1992).

3. Nicholas Murray: Bruce Chatwin, Bridgend, Wales 1993 och Nicholas Shakespeare: Bruce Chatwin, London 1999. 
Reseberättelsen - »le récit de voyage« - har en mycket lång historia som sträcker sig tillbaka till medeltidens pilgrimsfärder och renässansens upptäcktsresor. Dess verkliga storhetstid inföll under 1700-talet, då upplysningens törst efter fakta drev en lång rad vetenskapsmän och diktare att ge sig ut på expeditioner till den nya världen eller att kuska runt i sina egna länder för att sorgfälligt beskriva, mäta och väga allt de iakttog på sin färd. 1700-talet var också det sekel då den fiktiva, fantastiska eller utopiska reseskildringen blev en utbredd genre med Swifts Gulliver's Travels (1729) och Voltaires Candide (1759) som auktoritativa exempel. Redan på 1600talet hade överklassen i England och Frankrike dessutom haft för vana att sända iväg sina söner på en »Grand Tour« genom Europa, och därmed inleddes en lång tradition som skulle kulminera med romantikernas bildningsresor till de klassiska kulturländerna vid Medelhavet. Under 1800-talet bidrog naturligtvis den europeiska kolonialismen i Afrika och Asien till reseskildringens tilltagande popularitet. Många välkända romaner från slutet av 1800talet handlade om äventyrliga resor i exotiska länder - man behöver bara tänka på en författare som Joseph Conrad - samtidigt som symbolismens och den tidiga modernismens poeter gärna efterliknade Baudelaire och störtade "Au fond de l'Inconnu pour trouver du nouveau! «. Som Paul Fussell har visat florerade reseskildringen i den engelska litteraturen så sent som under mellankrigstiden, vilket givetvis hade sin förklaring i Storbritanniens imperialistiska förflutna. ${ }^{4}$

Efter andra världskriget avtog emellertid intresset för reselitteratur markant. »I den närmaste framtiden förväntar jag mig inte att stöta på särskilt "många reseböcker«, skrev Evelyn Waugh 1946 med hänsyftning inte bara på krigets ödeläggelse av många traditionella turistmål utan också på det faktum att krigsindustrin hade skapat nya, effektiva och relativt billiga transportmedel, exempelvis det jetdrivna flygplanet. ${ }^{5}$ Snart skulle vem som helst kunna resa jorden runt på mycket kort tid, och varför då läsa böcker om livet i fjärran länder? Ja, varför resa överhuvudtaget? Massturismen upplevdes av många författare och intellektuella som ett allvarligt hot mot resandet som sådant. »Jag önskar att jag hade levat på de riktiga resornas tid«, filosoferar Claude Lévi-Strauss 1955 i Tristes tropiques och drömmer sig tillbaka till en värld som fortfarande var jungfrulig och oförstörd, som fortfarande kunde upptäckas och utforskas, som fortfarande lät sig beskrivas av kartor med vita

4. Paul Fussell: Abroad: British Literary Traveling Between the Wars, New York 1980.

5. Citerat efter Michael Kowalewski, "The Modern Literature of Travel in M. Kowalewski (ed.): Temperamental Journeys. Essays on the Modern Literature of Travel, Athens, Georgia \& London 1992, p. 3. 
fläckar. ${ }^{6}$ Själva resandet hade gjort det omöjligt att resa, skulle man kunna sammanfatta den blaserade antropologens dilemma.

Därför var det än mer paradoxalt att det »riktiga« eller »klassiska« resandet på nytt skulle bli populärt under sextio- och sjuttiotalet. Paul Theroux, en av Chatwins vänner och viktigaste litterära inspirationskällor, har i sin bok Sunrise with Seamonsters (1985) försökt förklara denna märkliga omsvängning. Theroux skiljer mellan »real travelers", som ensamma ger sig ut i världen för att uppleva en sorts befriande alienation i den främmande miljön, och det han kallar "mock-travelers", i första hand turister och affärsmän, som oftast i grupp reser ut bara för att kunna återvända hem, eller snarare reser runt utan att någonsin lämna sina hem. Just på grund av att det finns så många pseudoresenärer i vår egen tid har det riktiga resandet åter blivit på modet, menar Theroux:

"Pseudoresandet [Mock travel] har frambragt ett enormt intresse för det krångliga, gammalmodiga resandet, med dess motbjudande mat och bedrövligheter och långa nätter. Det har också gett upphov till ett livligt intresse för reselitteratur och till övertygelsen att världen fortfarande är stor och främmande och, gudskelov, full av tomma platser där ingenting är som hemma. $\ll^{7}$

De som genomlevde sina tonår under sjuttiotalet känner omedelbart igen detta från sina egna eller sina kamraters resor på den transsibiriska järnvägen, till revolutionens Latinamerika, fattigdomens Indien eller mystikens Nepal. Ju mer besvärligt, tröttsamt och skitigt det hela var, desto större blev upplevelsen av att verkligen resa. Sådan tedde sig situationen av allt att döma också för den något äldre Chatwin när han 1974 gav sig iväg till Patagonien, världens ände eller »the uttermost part of the earth«, som denna otillgängliga och allt annat än romantiska del av Sydamerika har kallats.

Bakom sig hade Chatwin då en lysande men högst besynnerlig karriär på auktionsfirman Sotheby's i London. Efter att nätt och jämnt ha klarat sig igenom internatlivet vid Marlborough hade han som artonåring där tillträtt en tjänst med den föga imponerande titeln "porter« och en lika blygsam veckolön på sex pund, för att inom loppet av bara några år avancera till chef för den impressionistiska avdelningen. Han behärskade uppenbarligen tekniken att formulera koncisa presentationer av de ädla föremålen i firmans kataloger, och han beundrades av sina äldre kollegor för sitt kritiska "öga». Ingen kunde med samma självklarhet som Chatwin skilja ett original äkta

6. Claude Lévi-Strauss: Tristes tropiques, Paris 1955, p. 44.

7. Citerat efter Kowalewski: Temperamental Journeys, p. 6. 
verk fån en förfalskning, oavsett om det handlade om en Gauguin undangömd på ett gammalt slott i Skottland eller en primitiv träskulptur insmugglad från Benin. Det råder heller inga tvivel om att han fann sig väl tillrätta i rollen som kringresande konnässör eller att han fascinerades av de mondäna kretsar som auktionsfirman och dess direktör Peter Wilson satte honom i förbindelse med. Men så småningom gick det också upp för Chatwin att handeln med konst kunde vara en ganska obehaglig business. »Jag började märka att ting, hur vackra de än är, också kan vara skadliga. Konstvärldens atmosfär påminde mig om ett bårhus. 'Alla de underbara föremål som har passerat dina händer', brukade man säga - och jag betraktade mina händer och tänkte på Lady Macbeth«, erkänner han 1983 i berömd essä med titeln »I Always Wanted to Go to Patagonia - The Making of a Writer«. ${ }^{8}$

Till mytologin kring Chatwins person hör historien om hur han en morgon på det tidiga sextiotalet i New York vaknade upp nästan blind på bägge ögonen, något han tog som tecken på att han snarast borde lämna Sotheby's och ägna sitt liv åt väsentligare ting. Får man tro honom själv hade en ögonspecialist rekommenderat honom att vila blicken på långa och avlägsna horisonter. Hur som helst började han från och med nu att resa på »riktigt«först till Afghanistan, där han tillsammans med vännen Ralf Erskine försökte följa samma rutt som Robert Byron hade gjort i sin klassiska reseskildring The Road to Oxiana (1937), och sedan till östra Sudan, där han kom i kontakt med Beja-folket, vars nomadiska tillvaro drabbade honom som något av en uppenbarelse. Hemkommen till England skrev han in sig vid universitetet i Edinburgh för att samla material till en stor, vetenskaplig studie om nomadernas liv. Boken skulle heta »The Nomadic Alternative« och kanske framförallt demonstrera Pascals tes att människan ständigt måste befinna sig i rörelse för att inte förlora sitt förstånd. Att hans väldiga projekt var dömt att misslyckas insåg inte Chatwin förrän många år senare, och under tiden blev han tvingad att försörja sig som konst- och kulturskribent på The Sunday Times.

Mot bakgrund av denna biografiska exposé ligger det förstås nära till hands att uppfatta Chatwins Wanderlust som ett uttryck för en vantrivsel i kulturen à la Freud eller en kulturell primitivism av det slag Lovejoy och Boas har beskrivit i Primitivism and Related Ideas in Antiquity (1935). Men ingenting kunde vara felaktigare. Chatwin förblev en entusiastisk »art collector«i hela sitt liv, och som tydligt framgår av hans självbiografiska essä var det resan till Patagonien som gjorde honom till författare. Den viktigaste

8. Bruce Chatwin: »I Always Wanted to Go to Patagonia - The Making of a Writer« in Anatomy of Restlessness, p. 11. Essän publicerades första gången i New York Times Book Review, 2 August 1983. 
drivkraften bakom Chatwins nomadism var inte så mycket en flykt bort från civilisationen som en strävan att uppsöka civilisationens rötter. »Den här boken är skriven som svar på ett behov att förklara min egen rastlöshet parat med en morbid fascination för rötter", deklarerade han i ett av sina många utkast till »The Nomadic Alternative«. ${ }^{9}$ Kanske kunde man säga att Chatwin genom sitt vandrande och skrivande försökte agera ut en av den västerländska kulturens grundläggande metaforer, nämligen den som gör gällande att livet är en resa, en metafor som ju också skymtar bakom Pascals berömda diktum: »Vår natur ligger i rörelsen«.

Från den här tropen är steget givetvis inte långt till att betrakta även det intellektuella livet, till exempel skrivandet och läsandet, som en sorts resa. Michel Butor är en av de moderna författare som har ställt denna tankegång på sin spets. I en av sina mest kända essäer i ämnet leker han rentav med tanken om en ny vetenskap kallad »iterologi«, som skulle studera litteraturens förhållande till människans reslust. ${ }^{10}$ När man skriver eller läser en text följer man med blicken en rad tecken som utvecklar sig längs en rät linje och slutligen når fram till en viss destination, säger Butor. Denna fysiska rörelse är intimt förbunden med en psykisk, genom vilken författaren eller läsaren kan lämna tecknen på det vita pappret och transportera sig själv mycket långt bort i fantasin. Att skriva och att läsa är alltså att resa.

Enligt Butor kan man emellertid också vända på metaforen och påstå att resandet utgör ett slags skrivande och läsande. Förutsättningen för att man skall kunna klara sig i ett främmande land är att man åtminstone nödtorftigt lär sig att tyda de underliga tecken man överallt stöter på i naturen och i den sociala miljön. Själv lämnar man också alltid spår efter sig då man reser. Det berättas att soldaterna i Napoleons armé ville hugfästa sitt besök i Egypten genom hugga lös med sina sablar på den stora tempelbyggnaden i Karnak. Långt senare skulle amerikanska soldater sätta signaturen »Kilroy was here» överallt i det krigshärjade Europa. Också på de platser där en upptäcktsfärd eller en forskningsexpedition har dragit fram är vägen alltid kantad med tecken, här vanligtvis i form av minnesmärken, monument eller gravstenar. Det första - och väl egentligen enda - astronauterna gjorde på månen var som bekant att plantera sin flagga.

Moderna turister är som regel mer pietetsfulla. I stället för att inmuta det främmande territoriet med graffiti eller andra symboler kan man ju ta ett fotografi av den plats man besöker, sända ett brev eller ett vykort till sina vänner därhemma eller möjligen skriva en reseberättelse. Men även i sådana fall producerar man tecken som andra personer måste läsa eller tolka och

9. Shakespeare: Bruce Chatwin, London 1999, p. 14.

10. Michel Butor: »Le voyage et l'écriture« in Répertoire IV, Paris 1974, p. 13. 
som därmed skapar en viss föreställning och vissa förväntningar om platsen, mentala bilder som gärna blir till klichéer från vilka det kan vara svårt att frigöra sig då man upplever den främmande orten i verkligheten. Det var precis den sortens textualisering eller fiktionalisering av platsen som LéviStrauss såg som ett hinder för det autentiska resandet.

Det är mycket möjligt att det här handlar om något mer än en metafor. I själva verket kan det vara så - som Butor antyder och Chatwin säkerligen skulle instämma i - att läsandet och skriften har sitt ursprung i den primitiva människans jakt på villebråd eller vandringar från en boplats till en annan. För jägarna var det naturligtvis helt avgörande att kunna spåra viltet, och för herdarna var det viktigt att kunna avläsa såväl årstidernas växlingar som mer plötsliga förändringar i vegetation och väder. När herdarna slog sig ned som bofasta bönder såg de givetvis till att utmärka gränserna för sina betesmarker med tecken av olika slag, medan de folk som förblev nomader skapade referenspunkter i naturen genom att namnge och memorera särpräglade fenomen i landskapet - höga klippor, stora träd eller livsnödvändiga källor. Vandringen blev på det viset en fortlöpande skrift som kunde läsas av dem som följde i förfädernas fotspår. Hos urinvånarna i Australien lever detta skick fortfarande kvar, påpekar Butor. ${ }^{11}$ Aboriginernas besynnerliga sånger är inget annat än ett slags kartor över den väldiga kontinenten, där varje betydelsefull detalj i geografin har sin speciella historia.

Som bekant skulle Bruce Chatwin senare i sitt författarskap skriva en hel bok om dessa »tjuringa lines« eller »dreaming tracks«. I den fick han till sist möjlighet att sammanställa och strukturera sitt omfattande material av excerpter och anteckningar om nomadernas liv. Många antropologer har med rätta kritiserat honom för att i brist på förstahandskunskap om aboriginernas kultur popularisera de teorier som redan hade framlagts av den kontroversielle autodidakten Theodor Strehlow i ett verk med titeln Songs of Central Australia (1972). Men helt oavsett om Chatwins vidlyftiga spekulationer i The Songlines (1987) är vetenskapligt försvarbara eller ej säger de en hel del om förhållandet mellan hans eget vandrande och berättande. Att han gärna föreställde sig nomaderna i tidernas begynnelse som ett slags sjungande vandringsmän, vilka på en gång läste landskapet och formade naturen till en väldig bok, berodde förmodligen på att han själv var en utpräglat litterär resenär. Som en sådan karakteriserar han sig också i den föreläsning om Patagonien som han 1978 höll tillsammans med Paul Theroux för »The Royal Geographical Society« i London. »Paul och jag begav oss till Patagonien av helt olika skäl«, konstaterar Chatwin. »Men om vi överhuvudtaget bör betraktas som resenärer, är vi litterära resenärer. En litterär

11. Ibid, p. 15. 
referens eller förbindelse gör oss troligen lika upphetsade som ett sällsynt djur eller en ovanlig växt; och därmed kommer vi att beröra några av de fall i vilka Patagonien har inverkat på den litterära fantasin «. ${ }^{12}$

Som Heather Henderson har framhållit i en uppsats om den brittiska reselitteraturen från mitten av 1800-talet fram till idag är detta i och för sig inget ovanligt. »Det finns två sorters resenärer«, skriver hon, »de som försöker fylla ut de 'vita tomrummen' på kartan och de som reser för att uppleva platser som tidigare har blivit besökta och beskrivna. Somliga strävar efter att rista in sig själva på en blank sida, andra efter att läsa ett redan skrivet landskap. ${ }^{13}$ Till den sista kategorin hör samtliga de författare Henderson studerar, men hon visar också på en intressant skillnad mellan dem. Medan 1800-talets reseskildrare gärna använde sig av Bibeln och den klassiska litteraturen för att kunna orientera sig i de främmande länderna, tycks en modern reseberättare som Philip Glazebrook vara helt och hållet uppslukad av den litterära traditionen. Det är bara turister som intresserar sig för nutidens verklighet i andra länder, förklarar Glazebrook i sin bok Journey to Kars (1984). »Riktiga« resenärer är framförallt upptagna av de främmande ländernas historia, och de koncentrerar sig därför på vad tidigare resenärer har registrerat.

Vad som ytterligare bidrar till reseskildringens litterära prägel är givetvis det faktum att resenären i det här fallet från början har för avsikt att skriva en bok. Hans resa blir därför samtidigt en jakt på litterärt gångbart material. Självfallet underlättas detta sökande om resenären väljer att följa i andra reseberättares fotspår och skriva om deras skrivande. I princip skulle han lika gärna ha kunnat stanna hemma och med utgångspunkt i litteraturen dikta ihop en fullständigt fiktiv expedition till fjärran länder, vilket många reseskildrare genom tiderna faktiskt har gjort. Men ofta väljer den litteräre resenären att gå i dialog med sina föregångare och diskutera vem som egentligen har sett mest eller bäst.

Det finns onekligen något »bookish« också över Chatwins reseskildringar. Under sin färd genom Patagonien hade han, enligt egen uppgift, Mandelstams Resa till Armenien och Hemingways In Our Time nedpackade i ryggsäcken. ${ }^{14}$ Före resan hade han dessutom noga studerat vad Magellan, Darwin, W.H. Hudson, Lucas Bridges och andra upptäcktsresande har berättat om denna del av Sydamerika. Men om landskapet och naturen i Patagonien säger Chatwin själv nästan ingenting. Inte heller får man veta

12. Bruce Chatwin \& Paul Theroux: Patagonia Revisited, London 1985, p. 7.

13. Heather Henderson: »The Travel Writer and the Text: 'My Giant Goes with Me Wherever I Go« in Kowalewski, Temperamental Journeys, p. 230.

14. Chatwin, "I Always Wanted to Go to Patagonia - The Making of a Writer in Anatomy of Restlessness, p. 14 . 
särskilt mycket om landets olika typer av politiska och samhälleliga system. Hans bok är i gengäld späckad med referenser till den klassiska litteraturen och med häpnadsväckande poetologiska eller etymologiska utredningar. Vad beträffar Shakespeare, Donne, Swift, Coleridge, Poe, Baudelaire och Jules Verne finns det rentav uppslag till spännande litterära analyser i Chatwins text.

Dessutom skulle man kunna hävda att hans bok på ett övergripande plan är strukturerad i enlighet med ett välkänt litterärt mönster. Själv ansåg Chatwin att han hade skapat en modern variant av det som på engelska kallas "wonder voyage«, en genre i vilken det är vanligt att hjälten ger sig ut för att söka efter ett sällsamt djur eller ett dyrbart föremål, exempelvis ett gyllene skinn. ${ }^{15}$ Det föregivna målet för Chatwins quest är verkligen ett skinn, om än inte så gyllene som den grekiska mytologins. Det rör sig om en bit päls från en mylodont (en förhistorisk sengångare av betydligt större format än den vi känner i dag), som Chatwin i sin barndom hade sett i en vitrin hos sin farmor och som han inbillade sig härröra från en brontosaur.

Och likväl kan man konstatera att In Patagonia på ett avgörande sätt skiljer sig från de reseböcker Henderson diskuterar i sin artikel. Det är varken Historien eller Traditionen som står i centrum för Chatwins intresse. Tvärtom söker han upp en lång rad nulevande och udda personer i Patagonien för att forska i deras märkliga öden. Vad Paul Theroux och han själv har gemensamt är inte bara en fascination för litteraturen, betonar Chatwin i den tidigare nämnda föreläsningen: »Vi är också bägge fascinerade av exiler. Om resten av världen sprang i luften i morgon, skulle man i Patagonien finna ett förvånande tvärsnitt av jordens nationaliteter, vilka samtliga hade drivits mot denna 'exilens yttersta uddar', till synes bara därför att de faktiskt fanns där. ${ }^{16}$ Under sin resa stöter Chatwin på walesiska kolonisatörer, engelska gentlemen, persiska missionärer, ryska dissidenter, amerikanska blomsterbarn och tyska rasister - allihopa mer eller mindre vinddrivna existenser och allihopa i besittning av en mer eller mindre fantastisk berättelse. Det är framförallt deras historier Chatwin lyssnar till och skriver ned. Vad han fäster sig vid är inte Patagoniens eller något annat lands historia utan de kuriösa anekdoter som har förpassats till historiens marginal.

Förutom dessa tillfälliga inblickar i en rad samtida människoöden består In Patagonia av ett par, tre längre berättelser, som trots att de är fullt autentiska har något av legendens skimmer över sig. Dit hör förstås historien om Charley Milward, en avlägsen släkting till Chatwin, som blev strandsatt i Patagonien 1898, gjorde karriär inom skeppsbranchen, fungerade som både

15. Shakespeare op.cit., p. 310 .

16. Chatwin \& Theroux: Patagonia Revisited, p. $7 \mathrm{f}$. 
engelsk och tysk konsul under lång tid, och senare skulle komma över ett mylodont-skinn, varav han alltså sände hem ett litet stycke till Chatwins farmor i England. Dit hör också historien om anarkisten och fantasten Antonio Soto, som på 1920-talet försökte genomföra en revolution i Patagonien men som misslyckades, flydde och svekfullt lämnade sina kamrater i sticket. Dit hör sist men inte minst historien om Butch Cassidy och »the Sundance Kid «, de legendariska revolvermännen, som efter en lång serie förbrytelser i USA fann en tillflyktsort i det öde Patagonien. Vad som förenar dessa berättelser är givetvis att de handlar om outsiders, människor som har befunnit sig utanför samhällets lagar eller traditionella normer.

Eventuellt kunde man här peka på en intressant parallell - trots det stora avståndet vad gäller såväl kronologi som geografi - mellan Chatwins bok och Gérard de Nervals Le Voyage en Orient från 1851. Som Butor nämner tillkom denna märkliga reseberättelse i direkt opposition till Chateaubriands klassiska L'Itinéraire de Paris à Jérusalem (1811). ${ }^{17}$ Själv en outsider valde Nerval att följa en alternativ resrutt i förhållande till den äldre diktarens konventionella pilgrimsfärd. Medan Chateaubriand hade besökt i tur och ordning Rom, Athen och Jerusalem, förlade Nerval sina stationer till Kairo, Beirut och Konstantinopel. Därigenom framstod hans resa inte bara som en spegelvändning av föregångarens utan också som ett slags »underjordisk « version av den. Vad som fängslade Nerval var de bortglömda eller bortträngda kulturer som dolde sig under västerlandets officiella tradition med dess arv från antiken och kristendomen. Hans skildring kom av den orsaken också att röra sig i gränslandet mellan fakta och fiktion, verklighet och fantasi, noterar Butor. Om Chateaubriand hade rest i Historien, utforskade Nerval Historiens labyrintiska källarvalv, dess förvirrande mångfald av apokryfiska historier - och något liknande skulle man kanske kunna säga om författaren till In Patagonia.

Hur har då Chatwin burit sig åt för att väva samman patagoniernas disparata historier till en enda berättelse? Många kritiker har påpekat att det egentligen inte finns någon röd tråd i boken, att den snarast påminner om ett collage, en mosaik eller ett pussel, och däri har de förmodligen rätt. Men kanske är det just bristen på en logiskt sammanhängande form som utgör bokens grundläggande idé. Man bör komma ihåg att Chatwin hade ett förflutet som konstsamlare och att resan till Patagonien startade med hans fascination för ett sällsynt föremål i farmoderns Wunderkammer (som tyskarna kallar sådana skåp med glasdörrar där man förvarar suvenirer och andra egendomliga familjeklenoder). Vad han skulle samla på under sin resa var givetvis inte sällsynta djur eller dyrbara föremål men väl något annat. Det

17. Butor: "Le voyage et l'écriture« in Répertorie $I V$, p. 24. 
verkliga målet för hans quest var den goda historian, och med en samlares maniska iver adderade han helt enkelt den ena besynnerliga berättelsen till den andra. ${ }^{18}$

Att Chatwin framförallt var en stor samlare har många av hans närmaste vänner intygat. Konsthistorikern Hugh Honour har dessutom vittnat om hans märkliga förmåga att imitera andra människor, lägga sig till med deras talesätt eller mimik och snappa upp deras historier. Det fanns inget ont i Chatwins skvaller, försäkrar Honour:

"Han vårdade sina heliga monster som ett inslag i sin mentala kuriosamling. För han samlade på människor liksom han samlade på föremål och idéer och ord. Han fascinerades av idén om die Schatzkammer, dessa samlingar av naturliga och artificiella kuriositeter som var så populära på femton- och sextonhundratalet, och hans egen 'samling', som till största delen stannade kvar i hans huvud, liknade snarast dem. Hans inre var fyllt med ett osannolikt sammelsurium av abstrusa, exotiska, vilda och sofistikerade tankar. $\ll^{19}$

Om detta var något som gjorde Chatwin själv till en ganska säregen figur, är det säkerligen ingen ovanlig egenskap bland samlare. Enligt Walter Benjamin kan samlarens verksamhet rentav liknas vid en socialt omstörtande aktivitet. ${ }^{20}$ Samlaren bryter loss tingen från sina normala funktionssammanhang och arrangerar dem i en till synes godtycklig och irrationell ordning, som dock på ett djupare plan reflekterar samlarens personlighet eller subjektivitet. Vad som har betydelse för samlaren är inte tingens konventionella mening, deras bruksvärden eller bytesvärden, utan deras äkthet, och denna genuinitet erhåller tingen genom att placeras i en tradition där samlaren själv utgör det sista ledet. Tingens ursprung och historia är därför av största vikt för samlaren, men det är bara i kraft av samlaren själv som tingen får sin historiska bestämmelse eller sitt definitiva öde. Med hjälp av tingen och deras »objektiva« data skapar samlaren en magisk encyklopedi eller en privat världsordning, skriver Benjamin. ${ }^{21}$

18. Det kan här vara på sin plats att hänvisa till en av mina studenter på Københavns Universitet, Christel Hvalsøe Brinkløv, som för ett par år sedan skrev en mycket inspirerande uppsats om Chatwin, där just »jagten på den gode historie« stod i centrum.

19. Shakespeare op.cit., p. 7.

20. Walter Benjamin: Das Passagen-Werk in Gesammelte Schriften V:1 (hrsg. von R. Tiedemann), Frankfurt am Main 1991, p. 271 ff. Se även W. Benjamin: „Eduard Fuchs, der Sammler und der Historiker« in Gesammelte Schriften II:2, (hrsg. von R. Tiedemann \& H. Schweppenhäuser), Frankfurt am Main 1991, pp. 465-505.

21. Benjamin: Das Passagen-Werk, p. 274. 
Chatwin spekulerade själv en hel del kring samlandets existentiella betydelse. I ett föredrag hållet vid en auktion 1973, senare publicerat under titeln »The Morality of Things«, diskuterar han en rad psykologiska teorier som skulle kunna förklara människans begär att omge sig med sköna eller på annat sätt auratiska ting. Efter att ha kritiserat Freuds idéer om fetischismen kastar han fram sin egen dristiga hypotes:

»Jag vill nu be er att acceptera att ett konstverk utgör en metaforisk bekräftelse på innehavet av ett territorium, och ett uttryck för det folk som bor där. En afrikansk förfader-skulptur, liksom en målning av Gainsborough, kungör mannens, familjens eller stammens rätt till en specifik plats. Vi är alla bekanta med föreställningen om konstsamlandet som en territorium-skapande aktivitet. Samlaren utstakar sitt område på samma sätt som en hund märker en krets av lyktstolpar. Och vi kan nu föreställa oss att människans fixering vid ting, vilken Freud stämplade som en perversion, helt enkelt är hennes sätt att märka ut en plats där hon kan leva. Ting tycks vara livsnödvändiga för oss; att vara utan dem är att vara vilsen eller rubbad. $\aleph^{22}$

Det var denna syn på människans relation till tingen som han längre fram skulle gestalta i sina bägge romaner The Viceroy of Ouidah (1980) och Utz (1988). Den förra bygger på ett autentiskt levnadsöde och handlar om en skrupellös man, av Chatwin kallad Francisco Manoel da Silva, som i början av 1800-talet utvandrar från Brasilien, slår sig ned som slavhandlare i det forna Dahomey, skaffar sig enorma rikedomar och grundlägger en hel dynasti av svarta ättlingar. Huvudpersonen i den andra boken är en betydligt stillsammare existens vid namn Kaspar Joachim Utz, som i den kommunistiska erans Prag har vigt sitt liv åt att samla på Meissen-porslin men som till följd av sin judiska bakgrund även misstänker att denna passion kan vara uttryck för idolatri och blasfemi. Såväl da Silva som Utz är extremt possessiva till sin läggning, och likväl kan man konstatera att de representerar två radikalt olika typer av samlare. Medan slavhandlaren legitimerar sitt värv genom att reducera människan till ett ting bland alla andra, försöker Utz tvärtom projicera mänskliga egenskaper på sina älskade porslinsfigurer. Någonstans mitt emellan dessa hållningar finner man förmodligen Chatwins egen attityd som samlare.

Benjamins teori om samlarens "produktiva oordning« kan i alla händelser vara till stor hjälp när man söker förklara Chatwins intresse för excentriska eller apokryfiska berättelser. I stället för att underkasta sig en förhärskande

22. Bruce Chatwin: »The Morality of Things« in Anatomy of Restlessness, p. $180 \mathrm{f}$. 
kulturell tradition försöker han skapa en högst personlig ordning i de främmande diskursernas mångfald. Av den anledningen tycks författaren till In Patagonia också ha valt ut sådana berättelser som på ett eller annat vis återspeglar hans eget livsöde. Till syvende och sist handlar samtliga historier i boken om den rastlöshet och det utanförskap Chatwin själv upplevde. Men inte nog med det. Han har av allt att döma tillrättalagt, ja ibland förvanskat dessa historier så att de lättare skulle kunna fogas in i hans privata samling.

Många av de patagonier som porträtteras i Chatwins bok har i efterhand anklagat författaren både för att ha svikit deras förtroende och för att ha ljugit om deras liv. Det är svårt för en utomstående iakttagare att ta ställning till sådana beskyllningar, men i sin stora biografi om Chatwin har Nicholas Shakespeare försökt kontrollera sanningshalten i bokens berättelser och kommit till slutsatsen att inslagen av ren fiktion är ytterst få. »I allmänhet subtraherar Bruce inte så mycket från sanningen som han adderar till den«, konstaterar Shakespeare. »Han berättar inte en halv sanning utan en och en halv sanning. Hans prestation består inte $\mathrm{i}$ att ha beskrivit Patagonien som det är utan i att ha skapat ett land kallat Patagonien - ett nytt sätt att se, en ny aspekt på världen. Och på samma gång att ha återskapat sig själv. $\ll^{23}$

Det supplément Chatwin själv bidrar med består ofta i en sorts romantisering av verkligheten. När han i señora Eberhards hem finner en modern men helt ordinär stol av rostfritt stål omvandlar han den genast till en möbel designad av Mies van der Rohe. När han i Rio Pico möter en kvinnlig läkare från Ukraina, som i verkligheten bara hade läst ett par volymer av Agatha Christie, kan han inte låta bli att förvandla henne till en passionerad läsare av hans egna ryska favoritförfattare, bland annat Osip Mandelstam.

Ett annat grepp som sätter sin prägel på Chatwins prosastil består i en dramatisering av narrativa förlopp. I stället för att återge sina historier från den utanförstående berättarens perspektiv iscensätter han dem som en regissör, och byter följaktligen ut den indirekta anföringen med direkt tal. På ett ställe refererar han en historia om Butch Cassidy och »the Kid « som han har funnit i en annan bok, skriven av en infödd patagonier. I januari 1908 skulle »the bandoleros norteamericanos « ha dykt upp inkognito i La Mata för att råna en bank i den intilliggande byn Comodoro Rivadavia. »De stannade en vecka«, skriver Chatwin. »En morgon stötte en poliskonstapel på dem då de stod och sköt på stranden. 'Vi tränar bara', skojade de med polischefen, Don Pedro Barros, som undersökte deras Winchestergevär och med ett leende räckte tillbaka dem. ${ }^{24} \mathrm{Om}$ denna händelse överhuvudtaget har ägt rum, så är det naturligtvis ingen som vet vad som egentligen yttrades den

23. Shakespeare op.cit., p. 318.

24. Bruce Chatwin: In Patagonia, London1977, p. 52. 
där morgonen på stranden eller polisstationen, eller vilket minspel som sattes upp.

Chatwins romantisering och dramatisering av sitt narrativa stoff har föranlett en del kritiker att kategorisera In Patagonia som ett skönlitterärt och fiktivt verk. Är inte boken strängt taget en roman? Enligt min åsikt är den frågan felaktigt ställd. Det finns inget som säger att en subjektiv eller personligt färgad berättelse också måste vara påhittad. Man kunde lika gärna se Chatwins självsvåldiga behandling av patagoniernas historier som en strävan att konkretisera och levandegöra verkligheten, vilket i sin tur skulle kunna sättas i förbindelse med samlarens ambition att ge de döda tingen liv genom sin passionerade blick eller sin känsliga hand. Vad en samlare avskyr mest av allt är museer, förklarar huvudpersonen i Utz. »I ett museum vilket som helst dör föremålet - av kvävning och av allmänhetens blick medan det privata ägandet tillerkänner ägaren rätten och behovet att röra. Liksom det lilla barnet sträcker ut handen för att röra vid det föremål det namnger, återupprättar den passionerade samlaren, med ögat i fullständig harmoni med handen, tingets livgivande förbindelse med sin skapare. ${ }^{25}$ För en samlare är det helt avgörande att föremålen i hans ägo är autentiska, men villkoret för att de skall framstå som sådana är närvaron av ett skapande subjekt som kan återuppliva deras ursprung: lösryckta från sitt mänskliga sammanhang har de ingen »aura«, skulle Benjamin säga. Likadant förhåller det sig med de berättelser Chatwin återger i sin bok. Det verkligt fantastiska med dem är inte att de avviker från sanningen eller ter sig fullständigt osannolika utan tvärtom att de lyckas övertyga läsaren om sin egen trovärdighet, och detta intryck får läsaren just på grund av att de har filtrerats genom ett personligt temperament.

Kanske bör man i detta sammanhang erinra om att den allra tidigaste reselitteraturen var av fiktiv och fantastisk karaktär. Odysseus betraktades av antiken som den arketypiske lögnaren, och Lukianos gick (på 200-talet e.Kr.) så långt som att parodiera samtidens reseskildringar i ett allt annat än realistiskt äventyr kallat En sannfärdig historia. Den kanske mest kända reseberättelsen från medeltiden, Sir John Mandevilles Travels (ca. 1356), var också ren och skär dikt, även om den långt in på 1500-talet beundrades som ett autentiskt vittnesbörd om Österlandets under. Med renässansens upptäcktsfärder förändras emellertid villkoren för den reseskildrande litteraturen. Vad Columbus, Vespucci och andra berömda sjöfarare konfronterades med i den nya världen var en verklighet som överträffade alla traditionella föreställningar om det fantastiska. Gränsen mellan fakta och fiktion blev diffus: vad som tidigare hade hänförts till dikten blev plötsligt

25. Bruce Chatwin: Utz, London 1988, p. 20. 
fullt realistiskt, medan den vetenskapliga sanningen fick något osannolikt över sig. Därmed blev även reseberättarens roll en annan än tidigare. „ ̈̈ven om man givetvis ifrågasatte resenärens auktoritet, såväl som värdet av hans information, attraherades man av honom i hans egenskap av en ny sorts individ som tillhandahöll unika erfarenheter, vars sanningshalt inte så lätt kunde kontrolleras av andra /.../ och som inte lät sig underkastas traditionella eller dogmatiska världsbilder«, konstaterar Jenny Mezciems i en artikel om resenarrationens ursprung. ${ }^{26}$

Hur kunde en sådan "powerfully mysterious alien« övertyga sina läsare om att han talade sanning? Det är bland annat den frågan Stephen Greenblatt har försökt att besvara i sin bok Marvelous Possessions: The Wonder of the New World (1991). Greenblatt noterar att de tidigaste rapporterna från den nya världen är genomsyrade med beskrivningar av under eller underverk, och denna typ av erfarenheter vill han sätta i samband med renässansens filosofiska och estetiska diskurser, där just undret spelade en central roll, antingen som orsak (till den filosofiska spekulationen) eller som effekt (av den konstnärliga gestaltningen). Redan för Descartes hade undret framstått som människans naturliga respons på mötet med en förut obekant och följaktligen ofattbar realitet, skriver Greenblatt. Enligt Descartes överväldigas människan av undret till den grad att hennes föreställningsförmåga eller förstånd paralyseras. Därför är det också svårt att skilja mellan det objektiva och det subjektiva momentet i erfarenheten av ett under. Själva ordet (»under« eller »wonder«) betecknar både den yttre verklighet som subjektet konfronteras med och den förvåning eller undran som verkligheten väcker hos subjektet. Men just eftersom undret vittnar om det mänskliga subjektets tillkortakommande, dess andliga eller intellektuella begränsning, kan själva erfarenheten av dess existens knappast betvivlas: Undrets uttryck står för allt det som inte kan fattas, som knappast kan bli trott. Det fäster vår uppmärksamhet på trovärdighetens problem och insisterar samtidigt på erfarenhetens obestridliga, tvingande karaktär. $\aleph^{27}$

Greenblatt diskuterar flera intressanta konsekvenser av det underbaras närvaro i reselitteraturen, bland vilka åtminstone två tycks ha relevans även för studiet av ett modernt författarskap som Chatwins. Enligt Greenblatt förklarar mötet med det underbara varför den tidiga resenarrationen så ofta saknar en traditionell episk struktur och gärna sönderfaller i en mängd löst sammanfogade anekdoter. Då den absolut unika erfarenheten per definition

26. Jenny Mezciems, "'Tis not to divert the Reader': Moral and Literary Determinants in some Early Travel Literature« in P. Dodd (ed.): The Art of Travel. Essays on Travel Writing, London 1982, p. 2.

27. Stephen Greenblatt: Marvelous Possessions. The Wonder of the New World, Chicago 1991, p. 20 . 
inte kan jämföras med någon annan låter den sig heller inte inpassas i ett logiskt eller temporalt förlopp. En annan konsekvens är att berättelsen i hög grad kommer att kretsa kring berättarens egen person. Resenären är själv unik så till vida som han är den ende eller den förste som har upplevt undret. För att andra människor skall kunna acceptera hans ögonvittnesskildring krävs därför att han presenterar sig själv och noggrant redogör för sina personliga upplevelser. Ju mer hans berättelse fokuseras på det egna jaget, desto trovärdigare kommer den att framstå. Detta insåg redan den anonyme författaren till Mandeville's Travels när han omsorgsfullt berättade, om sin barndom och uppväxt i England, om hur många år han tjänade sultanen i Egypten, om hur han återvände hem och skrev ned sina upplevelser etc. - och detta förklarar givetvis också varför eftervärlden under så lång tid levde i tron att Sir John faktiskt hade existerat.

Med hänsyn till denna tradition på reseskildringens område är det föga meningsfullt att spekulera över i vilken utsträckning romanen eller vår tids fiktionslitteratur i övrigt har påverkat Chatwins berättarkonst. I stället borde man fråga sig om den sorts berättande som In Patagonia representerar möjligen har inverkat på romanens och fiktionens utveckling. Man brukar säga att romanen är en öppen och relativt modern genre, som kan härledas ur flera äldre litterära former. Eposet är en sådan form, romansen är en annan, historieskrivningen är en tredje, och därtill kommer ett påtagligt inflytande från dramatiken, liksom i modern tid från essäistiken och journalistiken. Men som Percy G. Adams har visat i sin stora studie Travel Literature and the Evolution of the Novel (1983) kan den tidiga romanen även knytas till reseskildringen. Att detta inflytande ofta har negligerats av forskningen beror kanske inte minst på att det är så uppenbart. ${ }^{28}$

Resan skulle mycket väl kunna ses som en prototyp för det vi kallar »intrig« eller "plot« i en roman. För att kunna sammanlänka olika episoder till ett kontinuerligt narrativt förlopp måste romanen förlägga sin handling till ett fysiskt rum av något slag, och vad är då naturligare än att gestalta skeendet som en rörelse i ett (verkligt eller inbillat) geografiskt rum? Hjälten som ger sig ut för att söka efter ett värdefullt objekt och som på sin väg möter både vänner och fiender, hjälpare och motståndare, är naturligtvis också en figur som har en paradigmatisk förebild i reselitteraturen. Digressionen eller den till synes onödiga utvikningen, som är så typisk för romanen men som så ofta har förbryllat romanteoretiker och narratologer, tycks även den kunna få sin enkla förklaring när man tänker på alla de

28. Adams pekar på en lång rad beröringspunkter mellan reseberättelsen och romanen sådana vi känner dessa genrer. Här nöjer jag mig med att räkna upp några av dem som förefaller grundläggande och som har uppenbar relevans för analysen av Chatwins reseböcker. 
avbrott, försinkelser och krångliga omvägar som brukar känneteckna en lang resa. Likaså skulle man kunna förklara romanens realistiska kolorit, dess mångfald av egendomliga anekdoter och besynnerliga detaljer, genom att hänvisa till en resenärs möte med en främmande och exotisk värld. Mer allmänt skulle man förmodligen kunna peka på reseberättelsen som en viktig förutsättning för den heterogenitet som en del kritiker (exempelvis Michail Bachtin) anser vara kännetecknade för romanformen. Sist men inte minst kan man konstatera att den explicite jag-berättaren i äldre tiders romaner har mycket gemensamt med berättaren i en traditionell reseskildring, där spänningen mellan det subjektiva och det objektiva, det romantiska och det realistiska, det fiktiva och det faktiska, är ett konstitutivt inslag.

Men varifrån härrör i så fall reseskildringen? Som Adams framhåller finns det lika många typer av reseberättelser som det finns typer av romaner, och någon gemensam formel för deras genealogi låter sig knappast uppställa. Vad som emellertid tycks vara särpräglande för reseskildringen är att den bygger på en mycket lång tradition som ytterst står i förbindelse med ett muntligt, arkaiskt berättande. Det råder inga tvivel om att reseskildringen har en av sina djupaste rötter i den tidiga form av äventyrsberättelser som Adams i Northrop Fryes efterföljd kallar »romance«. Utmärkande för »the romance« alltsedan dess första manifestationer i den grekiska litteraturen var just att den berättade om en hjältes vandring eller resa i ett främmande land. Odysseus' irrfärder ger vid handen att sådana historier även kunde förekomma i eposets och mytens värld, men enligt Adams måste man anta att motivet i sista hand går tillbaka på berättelser om autentiska resor. Innan människan började resa i fantasin och i dikten torde hon ha företagit underbara resor i verkligheten.

I sin berömda uppsats »Der Erzähler« (1936) hävdar Walter Benjamin att det finns två figurer som förkroppsligar den arkaiske berättaren. Den ena är just resenären eller den handelsresande sjöfararen, som kunde berätta sällsamma historier om främmande länder när han återvände hem. Den andra är den bofaste jordbrukaren, som av det enkla skälet att han stannade hemma var förtrogen med ortens traditioner och kunde samla folks erfarenheter och berättelser till ett kollektivt minne. I själva verket är dessa bägge figurer dialektiskt förbundna med varandra, menar Benjamin. För att berättarkonsten skulle kunna utvecklas i hela sin sociala och historiska bredd måste de vid någon tidpunkt ha strålat samman i en enda person, till exempel i den medeltida hantverkaren, som å ena sidan var stationär men å andra sidan arbetade tillsammans med kringvandrande gesäller - och som själv hade rest runt som lärling innan han blev mästare. Hos hantverkaren förenades alltså kunskapen om det främmande med kunskapen om det förgångna. ${ }^{29}$ 
Kanske kunde man påstå att det också är dessa bägge gestalter som strålar samman i Bruce Chatwins person. Som resenär var Chatwin ständigt på jakt efter det okända, exotiska och excentriska; i sin egenskap av samlare hyste han stor respekt för genealogi, folkliga traditioner och konstnärligt hantverk. Med sin aldrig publicerade bok om nomader ville han på en gång förklara sin egen rastlöshet och komma tillrätta med sitt "morbida« intresse för rötter, och hans tryckta författarskap skulle i stor utsträckning kretsa kring denna ambivalens. Vid sidan av sina äventyrliga reseböcker skrev han exempelvis On the Black Hill (1982), av många kritiker ansedd som hans bästa roman, vars handling är förlagd till det lantliga Wales och vars huvudpersoner är två tvillingbröder som bor på en och samma gård i hela deras liv. Den här boken blir inte mindre intressant av det faktum att den tematiserar själva konflikten mellan vandraren och stugsittaren. Tvillingarna är till det yttre lika som bär men på ett djupare plan varandras diametrala motsatser. Lewis är utåtriktad, handlingskraftig och betagen av såväl kvinnor som opålitliga flygmaskiner, medan Benjamin är mer feminin till sin läggning, en smula intelligentare och konstnärligare än sin bror, men samtidigt den som styr i hemmet och har hand om hushållskassan. Man behöver inte bekänna sig till någon sofistikerad psykoanalytisk teori för att tolka detta dubbelgångarmotiv som ett uttryck för en spaltning inom författarens egen personlighet.

Hos resenären och samlaren Bruce Chatwin skulle man med andra ord kunna bevittna ett slags pånyttfödelse av den berättare som enligt Benjamin har trängts undan av de moderna massmedierna och i viss mån ersatts av romanförfattaren. Men hur lyckades Chatwin överbrygga motsättningen mellan dessa bägge roller? Med hantverkarna på medeltiden hade han inte särskilt mycket gemensamt, och det är svårt att se hur nomadens egendomslösa tillvaro skulle kunna förenas med en samlares possessiva mani.

Greenblatts analyser av den tidiga reselitteraturen kretsar i hög grad kring en sådan oförsonlig konflikt. Från och med renässansen kom »the language of the marvelous« att legitimera erövringen och utplundringen av främmande kontinenter, hävdar han. Medan Mandeville's Travels avvisar varje form av jordiskt ägande för att i stället hylla vandrandet som sådant, det ständiga sökandet efter en underbar men ogripbar verklighet, vittnar Columbus' nyktra rapporter från Amerika om en praktisk och målmedveten strävan att ta den fantastiska verkligheten i besittning. Ett stort problem för Columbus var givetvis att moraliskt och juridiskt rättfärdiga spanjorernas kolonisering av den nya världen. Med vilken rätt kunde han eller hans upp-

29. Walter Benjamin: „Der Erzähler« in Gesammelte Schriften II:2, (hrsg. von R. Tiedemann \& H. Schweppenhäuser), Frankfurt am Main 1991, p. 440. 
dragsgivare göra anspråk på de landområden som hans skepp förde honom till? I kraft av vilken högre princip kunde han reducera hela folkslag och deras uråldriga kulturer till den spanska statens egendom? Enligt Greenblatt fann Columbus en sorts lösning på problemet i den kristna namngivningens mysterium. När Adam gav namn åt djuren utgick han från en gudomlig insikt om kreaturens rätta natur eller sanna väsen. Därför kom hans rent lingvistiska handling (hans »speech-act») också att legitimera hans oinskränkta makt över skapelsen. Adam förstod således att sätta namn på det underbara eller fantastiska, men denna handling var själv ett under eftersom den hade framgått ur Guds outgrundliga vishet. Det är detta underverk som Columbus gång på gång repeterar i sina skrifter, inte bara som ett uttryck för sin egen oförställda förvåning utan också som en medveten retorisk strategi. "Ägandekravet grundas på undrets makt«, konkluderar Greenblatt. $^{30}$

Det finns mycket som talar för att Chatwins berättarkonst har sina yttersta förutsättningar i en sådan retorik. Chatwin använde utan tvivel sitt magiska språk och sin särpräglade berättarteknik för att inlemma främmande platser, miljöer och människor i sitt eget imaginära universum. Trots att han ständigt befann sig på resande fot och upplevde samma horreur du domicile som Baudelaire förblev han en ganska typisk representant för den brittiska kulturen och litteraturen. Liksom en "Lawrence of Arabia" lät han sig uppslukas av det Andra bara i förhoppning om att kunna transformera det till sin egen vision. ${ }^{31}$ Och likväl finns det något i den karakteristiken som inte riktigt stämmer. Som författare samlade Chatwin på berättelser, inte på ting, och en berättelse kan aldrig tas i besittning av en enskild individ. Den lever bara genom att berättaren meddelar sig med - eller delar med sig till - andra individer. Om det är fullt möjligt att samla på berättelser, går det inte att äga dem. En berättelse tillhör i någon mening alltid de andra, de som lyssnar till den, transformerar den och sprider den vidare. Ja, den sanne berättaren exempelvis upphovsmannen till Mandeville’s Travels eller författaren till In Patagonia - är själv en sådan främling, vars röst förlorar sig i ett avlägset fjärran eller i ett dunkelt förflutet. Den sanne berättaren måste alltid resa, i

30. Greenblatt: Marvelous Posessions, p. 83.

31. T.E. Lawrence är en av de västerländska författare Edvard Saïd har anklagat för en sorts "latent orientalism«. Samtidigt som Lawrence uppenbarligen kände en genuin sympati för den arabiska kulturen, och under långa perioder själv försökte leva som en arab, skulle han ha förvandlat Orienten till ett västerländskt och i sista hand personligt projekt. "The great drama of Lawrence's work is that it symbolizes the struggle, first, to stimulate the Orient (lifeless, timeless, forceless) into movement; second, to impose upon that movement an essentially Western shape; third, to contain the new and aroused Orient in a personal vision, whose retrospective mode includes a powerful sense of failure and betrayal", skriver Saïd i Orientalism. Western Conceptions of the Orient, London 1978, p. 241. 
verkligheten eller i fantasin, i rummet eller i tiden, för att kunna samla ihop sina mer eller mindre underbara historier. 